\title{
The Role of the Environmental Sphere in Factors Affecting Performance and in Performance Dimensions in the Utility Sector: A Literature Review
}

\author{
Fabio De Matteis ${ }^{1}$, Alessandra Tafuro $^{2}$, Daniela Preite $^{3} \&$ Giuseppe Dammacco $^{1}$ \\ ${ }^{1}$ University of Bari, Italy \\ ${ }^{2}$ University of Salento, Italy \\ ${ }^{3}$ University of Milan, Italy \\ Correspondence: Fabio De Matteis, University of Bari, Italy.
}

Received: November 23, 2021

Accepted: December 25, 2021

Online Published: January 5, 2022

doi:10.5430/ijba.v13n1p30

URL: https://doi.org/10.5430/ijba.v13n1p30

\begin{abstract}
Considering the environmental impacts of utility activities and the lack of literature systematic understanding of the different factors affecting utility performance with a specific consideration of the environmental sphere, this article tries to bridge this gap conducting a literature review on factors affecting utility performance. An aspect of novelty of the paper is represented by the clusterization of literature (also useful for future studies) that considers the environmental sphere both among factors of influence and as performance dimensions. The analysis conducts to conclude that both as influencing factors and as performance dimensions, the environmental role should be more widely and deeply investigated by literature. The research highlights some managerial implications: the appointment of managers should consider their "green skills" as factor influencing performance of the utilities; the need to develop managerial tools to make the decision-making process effective and efficient also in the environmental sphere.
\end{abstract}

Keywords: utility performance, environment, literature review, clusterization

\section{Introduction}

The utility sector represents a broad articulated field of study and the complexity of this sector derives from at least four aspects that are, at the same time, elements of interest in research focusing on utilities' performance.

The first aspect is the numerousness of services' sectors (water, waste management, gas, electricity, etc.) and their different regulations (Guerini et al., 2018). This generates the coexistence of small, medium, and large companies serving different territories and residents, as either multi-utilities or mono-utilities (Guerrini et al., 2013).

The second aspect concerns the different governance profiles characterizing these organizations (private ownership, totally publicly owned, public-private ownership). For example, Public Sector organizations can choose from a range of different methods (e.g. in-house or outsourced local public services) to provide public services (Calabrò et al., 2013).

The third aspect is the high level of public financial resources deployed by utilities. They require a significant amount of expensive infrastructure and consequently they generate large amounts of debt: considering that a big part of utilities is publicly participated and financial resources continue to be public, even at the peak of private participation (Hukka and Vinnari, 2007). This implies a large amount of public resources invested in this kind of organization and, consequently, an interest in public resource economics (Cetrulo et al., 2020).

During the last century, the field of public services experienced profound changes worldwide (Osborne and Brown 2005). The utilities developed mainly as a combination of private and public functions, while later they were characterized by large-scale nationalization until the eighties when this dominant model began to change (Parker, 2003). All over the world, governments have supported the privatization of public services for many years now. Probably, the search for better performance is the most important reason this option is based on (Megginson et al., 1994), although many other possible reasons have been highlighted (Yarrow, 1986). 
Consequently, processes and tools for performance assessment in the analysis of utilities are gaining in popularity (Simões et al., 2010).

To this regard, considering methods of performance measurement, it is also important to know what the factors affecting the performance of utilities are. It then becomes important to analyze these factors in order to keep managers and owners informed, so that they can make decisions also based on empirical studies. This aspect is relevant also because the failure to consider specific performance drivers has recently led some utilities into bankruptcy and financial collapse (Guerrini et al. 2017).

An increasing attention is aimed at sustainability also in terms of environmental and social performance (Filbeck and Gorman, 2004), following the Corporate Social Responsibility approach (Ait Sidhoum and Serra, 2017).

In particular, a relevant aspect related to utility management, is represented by the impact of the utility activity on the environment. In fact, the utility sector refers to companies that provide basic services, such as water, electricity, oil, natural gas and wastewater services, related to the use of natural resources, and waste management, related to environmental protection (Muehlenbachs et al. 2013). Environmental issues are a critical factor for today's utility assessment, considering that they are often associated with water consumption, wastewater, solid waste management and energy use and emissions to air.

According to Landis (2015), there is a knowledge gap related to utilities' level of engagement in environmental sustainability planning and sustainable practices. Considering the environmental impacts of utility activities and the above mentioned lack of literature systematic understanding of the different factors affecting utility performance with a specific consideration of the environmental sphere, this article tries to bridge this gap conducting a literature review on factors affecting utility performance.

Therefore, having illustrated the importance and the complexity of the issue and considering the consequent managerial fallouts, the following research questions, which will be the base of the development of this study, come to surface:

R.Q. 1: "What factors affect utility performance and what is the role of environmental variables?"

R.Q. 2: "What are the performance dimensions investigated and what attention is paid to the environmental dimension?"

The literature on utility performance is abundant and comes from different fields of research, but it lacks a systematic understanding of the different factors affecting performance. Consequently, this work applies the literature review methodology and it is characterized by the following novelty elements:

- the proposal of a cluster scheme for literature that investigates the relationship between influence factors and dimensions of utility performance;

- the analysis of the literature on factors affecting utility performance is conducted with a specific consideration of the environmental sphere;

- the studies taken into consideration are only those in which quantitative methodology is applied (in fact, this methodology allows scholars to investigate the relationship between factors of influence and performance dimensions).

The analysis developed in this work highlights that the environmental role should be more widely and deeply investigated by literature, both in terms of influencing factors and as performance dimensions. Furthermore, this work suggests possible lines of research not investigated by the analyzed literature and provides useful information for managers of utilities.

This paper is structured as follows. Section 2 shows the method applied (research methodology and steps followed) to develop the study. Section 3 explains the sample clustering designed on the basis of prior literature. Section 4 reports on the results of literature analyses. Section 5 discusses the results obtained and, finally, section 6 proposes some final remarks.

\section{Methodology}

Considering the lack of a systematic understanding of the different factors affecting utility performance, the methodology used in this paper is the literature review. Furthermore, this methodology is functional to the objective of the paper defined by RQ1 and RQ2. Finally, the application of the literature review methodology seems to be appropriate and reasonable, especially for issues related to utility performance domain, (Ensslin et al., 2015) which requires the overlap of different academic disciplines. 
The literature review methodology was applied using a research design that defines comprehensible search choices and clear selection criteria.

Adapting Wolfswinkel et al. (2013), the following 8 steps have been followed (Table 1).

Table 1. Steps of the literature review methodology

\begin{tabular}{|c|c|c|c|}
\hline n. & Step & Description & Targeted goal \\
\hline 1 & Set search criteria & $\begin{array}{l}\text { Define the main criteria under developing the } \\
\text { following steps of the literature review process }\end{array}$ & $\begin{array}{l}\text { Narrow the literature review only to scientific } \\
\text { articles using quantitative methodology } \\
\text { related to the research topic }\end{array}$ \\
\hline 2 & Select databases & Identify the database to be used & $\begin{array}{l}\text { Focus the search on the most relevant } \\
\text { databases }\end{array}$ \\
\hline 3 & Choose keywords & $\begin{array}{l}\text { Identify keywords driving the articles selection } \\
\text { in the database }\end{array}$ & $\begin{array}{l}\text { Select the keywords that guarantee } \\
\text { significant usefulness and pertinence to the } \\
\text { topic }\end{array}$ \\
\hline 4 & Search articles & $\begin{array}{l}\text { Search for articles that include specific } \\
\text { keywords in title/abstract/full body }\end{array}$ & $\begin{array}{l}\text { Single out the literature more closely related } \\
\text { to the research topic }\end{array}$ \\
\hline 5 & Remove duplicates & $\begin{array}{l}\text { Remove journal articles that emerge in multiple } \\
\text { databases }\end{array}$ & $\begin{array}{l}\text { Exclude duplicate articles since they do not } \\
\text { provide additional value }\end{array}$ \\
\hline 6 & Refine the sample & $\begin{array}{l}\text { Read abstract, introduction and conclusion of all } \\
\text { articles to exclude potential false positives }\end{array}$ & $\begin{array}{l}\text { Dismiss journal articles that lack a significant } \\
\text { lassociation or connection to overall review } \\
\text { topic }\end{array}$ \\
\hline 7 & Test the completeness & $\begin{array}{l}\text { Compare the selected literature set with a recent } \\
\text { literature review article on a similar topic }\end{array}$ & $\begin{array}{l}\text { Verifying the completeness of our literature } \\
\text { t set matching it with the reference cited in the } \\
\text { comparison article }\end{array}$ \\
\hline 8 & Analyze the selected sample & Read the full text of the articles & $\begin{array}{l}\text { Clustering and analyses of the literature } \\
\text { sample to answer the research questions }\end{array}$ \\
\hline
\end{tabular}

Generated by authors

Applying step 1, the focus was on specific kinds of articles that comply with the following criteria:

- $\quad$ scientific papers published under blinded peer review; including only academic journal articles (excluding working papers and conference papers) in the literature search criteria. This decision maintains the rigorousness of the review;

- $\quad$ articles that use only quantitative research methods;

- $\quad$ articles that analyze the links between different factors of influence and the utility performance;

- articles with results that can be considered useful for utility management and not only with technical implications.

Our review is organized around those 4 criteria that are highly specific and, therefore, it leads to the collection of articles that was not particularly large. On the one hand, this aspect is balanced by the choice of keywords (using the keywords selection method described below); on the other hand, the use of these criteria allowed us to focus the attention on the specific aspects covered by this research.

The quest for published journal articles considers two major databases: Web of Science and Scopus. The articles selected span over 20 years, starting as early as 2001 with the latest having been published in 2020 .

The selection of these databases (step 2) followed previous literature (e.g.: Wilhelm and Ruhlandt, 2018).

In choosing the keywords (step 3), it is necessary to create a balance when searching by, on the one hand, making the search comprehensive enough to encompass everything on the topic; while, on the other, making the search precise enough only to capture those results that are specifically relevant. Consequently, the choice was to use a balanced 
criterion to select the keywords that can be considered a mixed criterion between the comprehensive and precise criteria (Table 2).

Table 2. Keywords selection matrix

\begin{tabular}{llll}
\hline Keywords definition & \multicolumn{1}{c}{ Comprehensive criterion } & Precise criterion & Balanced criterion \\
\hline Advantage & $\begin{array}{l}\text { Increases the possibility to find all } \\
\text { articles on the subject, without } \\
\text { missing relevant papers }\end{array}$ & $\begin{array}{l}\text { Increases the possibility to find the } \\
\text { most relevant articles on the topic, } \\
\text { reducing the collection of irrelevant } \\
\text { results }\end{array}$ & $\begin{array}{l}\text { Increases the possibility of finding the } \\
\text { most relevant articles on the topic, } \\
\text { collecting articles } \\
\text { intermediate relevance and avoiding } \\
\text { the collection of irrelevant results }\end{array}$ \\
\hline Disadvantage & Risk of collecting irrelevant papers & $\begin{array}{l}\text { Risk of not intercepting relevant } \\
\text { papers }\end{array}$ & $\begin{array}{l}\text { Risk of classifying many papers as } \\
\text { intermediately relevant, spending lot } \\
\text { of time deciding if they should be } \\
\text { included or not in the sample }\end{array}$ \\
\hline
\end{tabular}

Generated by authors

The most common terms on the subject analyzed in this paper are "environment", "performance", "water utility", "efficiency", "productivity", and "utilities". Following the balanced criterion, the identified keywords are: "utility performance" and/or "environment". Indeed, "utility performance" is a broad term that goes in the direction of comprehensiveness, while "environment" restrict the focus of research to a more precise field. Furthermore, the use of the keywords "utility performance" and/or "environment" allowed us to collect all papers focused on utility performance considering different performance dimensions. Among these papers, the focus was only on those that analyze the relationship between factors of influence and utility performance.

Introducing the keywords in the chosen databases, we selected the articles that include them in the title/abstract (step 4). The complete search resulted in a list of 246 articles that represents the starting point of the process needed to define the research sample. Of these 246 articles, the search finds 105 articles in Scopus, 141 in Web of Sciences.

This initial collection showed the presence of duplicates. Therefore, step 5 is the removal of 63 articles that were listed in both the databases.

Then, some articles were excluded (step 6) on the basis of the following criteria, adapting Schanes et al. (2018): articles that do not use quantitative research methods and articles that do not analyze the links between different factors of influence and the utilities performance. Applying these criteria and reading the abstract, the introduction and the conclusion of all articles, 156 false positives have been excluded. This allowed us to refine and narrow the sample in a more precise way in order to answer the research questions.

Following Eloranta and Turunen (2015), the completeness of the literature set (step 7) has been tested using the systematic literature review focused on the performance of utilities contained in Ensslin et al. (2015). Comparing our set to the references contained in the sample of Ensslin et al.'s review (16 articles), the literature collection has been completed by including one additional article.

The previous seven steps lead to defining a sample of 28 articles. Figure 1 highlights the literature sampling procedure, showing both the number of collected or eliminated (in brackets) articles, and the steps of literature review for each phase of the procedure.

An aspect of novelty of this analysis is represented by the selection of papers analyzing different sectors of utility activity. In effect, recent literature argues the need to shift towards a cross-sectoral approach to develop greener infrastructure systems by enhancing their efficiency level (Florentin, 2019). This leads to defining a multi-sector sample, while generally, literature focuses on one specific sector. In particular, the sectors of activity of the utilities considered in the 28 articles sampled are the following: water service in 50\% of the sample (14 articles); waste management in $18 \%$ of the sample ( 5 articles); electricity in $11 \%$ of the sample ( 3 articles); oil and gas in $7 \%$ of the sample ( 2 articles); multiple sectors in $11 \%$ of the sample ( 3 articles); sewerage service in $3 \%$ of the sample ( 1 article). 


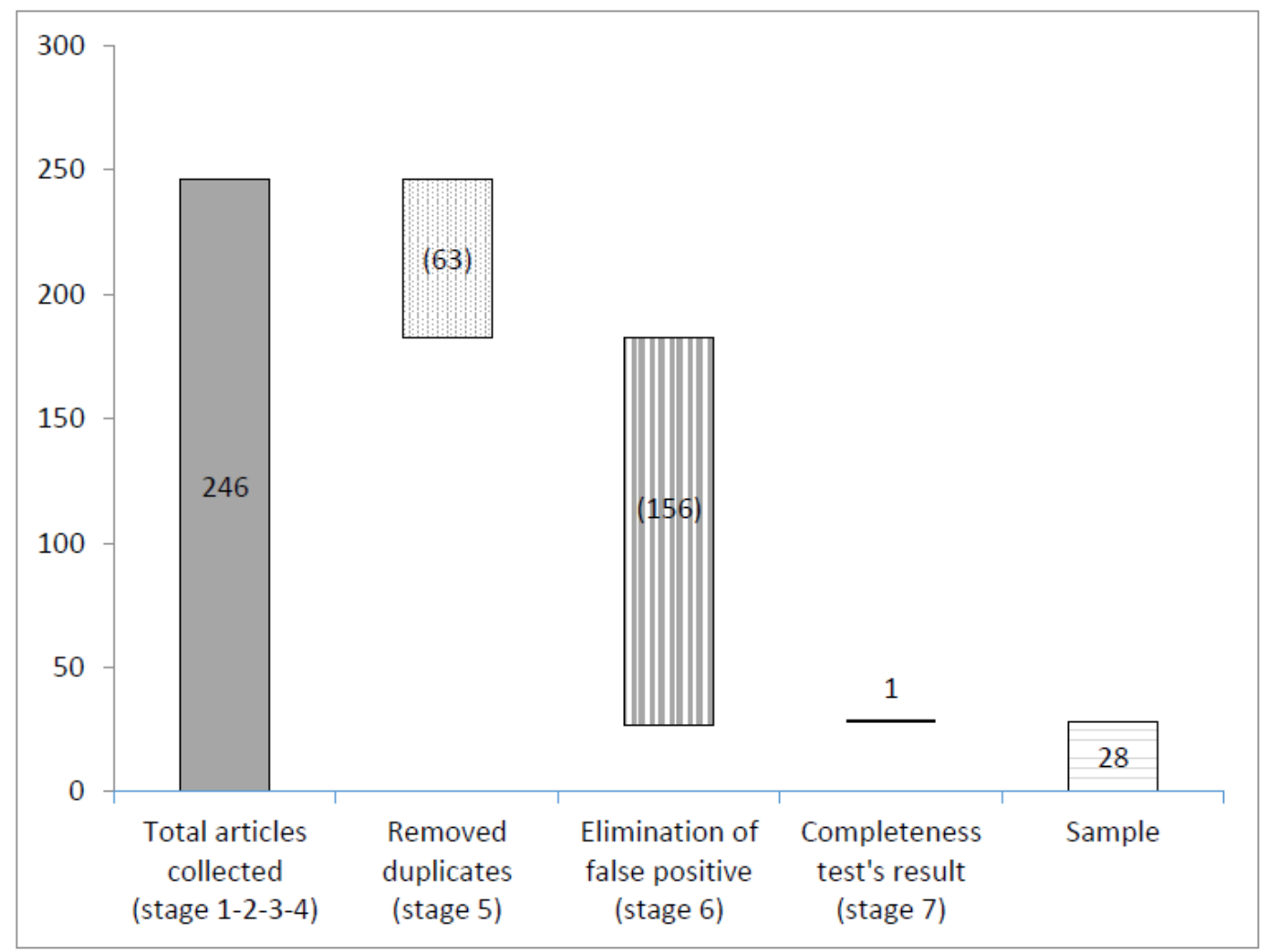

Figure 1. Literature sampling procedure

Generated by authors

In step 8, the selected sample has been analyzed reading the full text of the articles. Through the analysis, various thematic codes were inductively derived and articles were classified in an iterative process to identify the main groups of factors impacting utility performance. The same process was followed in order to define the principle dimensions in which the concept of performance in the sampled articles is declined (Wolfswinkel et al., 2013).

Considering the complexity/articulation of this step 8, it is further described in detail in the next two sections.

\section{Sample Clustering}

The complexity of the theme object of this analysis leads to identify different categories regarding the factors affecting utility performance, and different dimensions that scholars consider in the concept of performance. Consequently, we propose a clusterization scheme (Webster and Watson 2002) that could be used to analyze and examine the selected body of literature and, at the same time, that could be useful for future studies' development.

The sampled literature is clustered into three categories with regard to factors influencing utility performance: governance, size and positioning. A fourth category is represented by the performance dimensions, as it is considered in different ways by various authors of the articles composing the sample.

Governance (category 1) is one of the most important dimensions affecting utility performance (Beecher, 2013), considering that ownership and boards of directors play crucial roles (Adams et al. 2010). Berg and Marques (2011) highlight that many quantitative studies on water and sanitation utilities are aimed at testing the influence of ownership on efficiency.

Moreover, a lot of literature investigates the classic issue represented by the dilemma between public and private management (Simões and Marques, 2012). Another frequently debated corporate governance issue that can affect performance is represented by the board composition, as it can influence the board's deliberations and ability to control top management decisions. Less attention has been paid to the potential role that regulatory policies (Ehrhardt and Janson, 2010) can play in improving or decreasing performance (Sarr, 2015). Berg and Marques (2011) analyze the role of incentive related to different governance systems that also include external regulation. 
With reference to size (category 2), an important role is played by environmental variables that are often related to the dimensional aspect of the utility such as the extension of the served area (e.g. Thanassoulis, 2002).

Population density is a relevant environmental variable that may affect waste utility performance that can be measured by the ratio of the number of inhabitants per square kilometers of the served area (Koushki et al., 2004). Benito et al. (2011) demonstrate that population density can damage efficiency because circumscribed and densely populated territories can reduce the opportunity to use large specialized equipment. In fact, when this kind of equipment is replaced by less productive manual activities, the effect of narrow and populated areas erodes cost savings achieved due to the shorter distance among pickup points. In addition, according to Passarini et al. (2011), the population served seems to affect the rate of separate collection negatively, which is higher in the rural areas, characterized by low population density, compared to municipality territories.

Guerrini et al. (2017), analyzing the waste collection sector, consider - among the others - the average household size, the tons of waste collected per load and the collection method.

Another typology of environmental variables effectively related to the environmental attitude of utilities is represented by the investment for environmental protection (Sueyoshi and Goto, 2009).

According to the conclusions formulated in the relevant literature (DeWenter and Malatesta 2001), the size of the organization can affect the economic/financial performance and can be considered in terms of a logarithmic value of the total assets.

A further aspect related to the size category is represented by the field/sector of activity that can have an influence on the economic performance (Monteduro, 2014).

Many scholars consider human resources, such as the employee characteristics, one of the variables influencing utility performance (e.g. Marques, 2008; Bobde and Tanaka, 2018).

Positioning (category 3) is considered as the geographical location - in terms of socio-economic environment (Monteduro, 2014) and in terms of morphological features (Guerrini et al. 2011) - that may affect economic performance.

In relation to the performance dimensions (category 4), literature analyzes utility performance (in terms of factors affecting it) principally as: technical efficiency (Marques and Simoes, 2009) or productivity (relationship between input consumed and output produced); effectiveness (e.g. Mbuvi et al 2011, consider the quality and reliability of the services provided); economic and financial results, based on the measures arising from the accounting system (Ding et al., 2014).

The environmental dimension of performance (Schultze and Trommer, 2012) is increasingly important in the broader realm of corporate social responsibility (Ait Sidhoum and Serra, 2017).

For each category, the following sub-categories (Figure II) based on the literature mentioned above, have been identified:

- governance is analyzed considering ownership and governance structure (1.1), political and/or institutional influence (1.2);

- $\quad$ size is divided into four components represented by:

1. environmental variables (2.1) that are: territory served (2.1.1), population/customers served (2.1.2), technical characteristics of the service (2.1.3); environmental investment/expenditure (2.1.4);

2. assets/sales (2.2),

3. sector/service diversification (2.3);

4. human resource (HR) characteristics (2.4);

- $\quad$ positioning is interpreted in the sub-category represented by geographical localization (3.1).

With reference to the category "performance" (cat. 4), three main meanings have been attributed by the scholars to the concept of performance: organizational/operational (efficiency/effectiveness) performance (4.1); accounting performance (4.2) and environmental performance (4.3). 


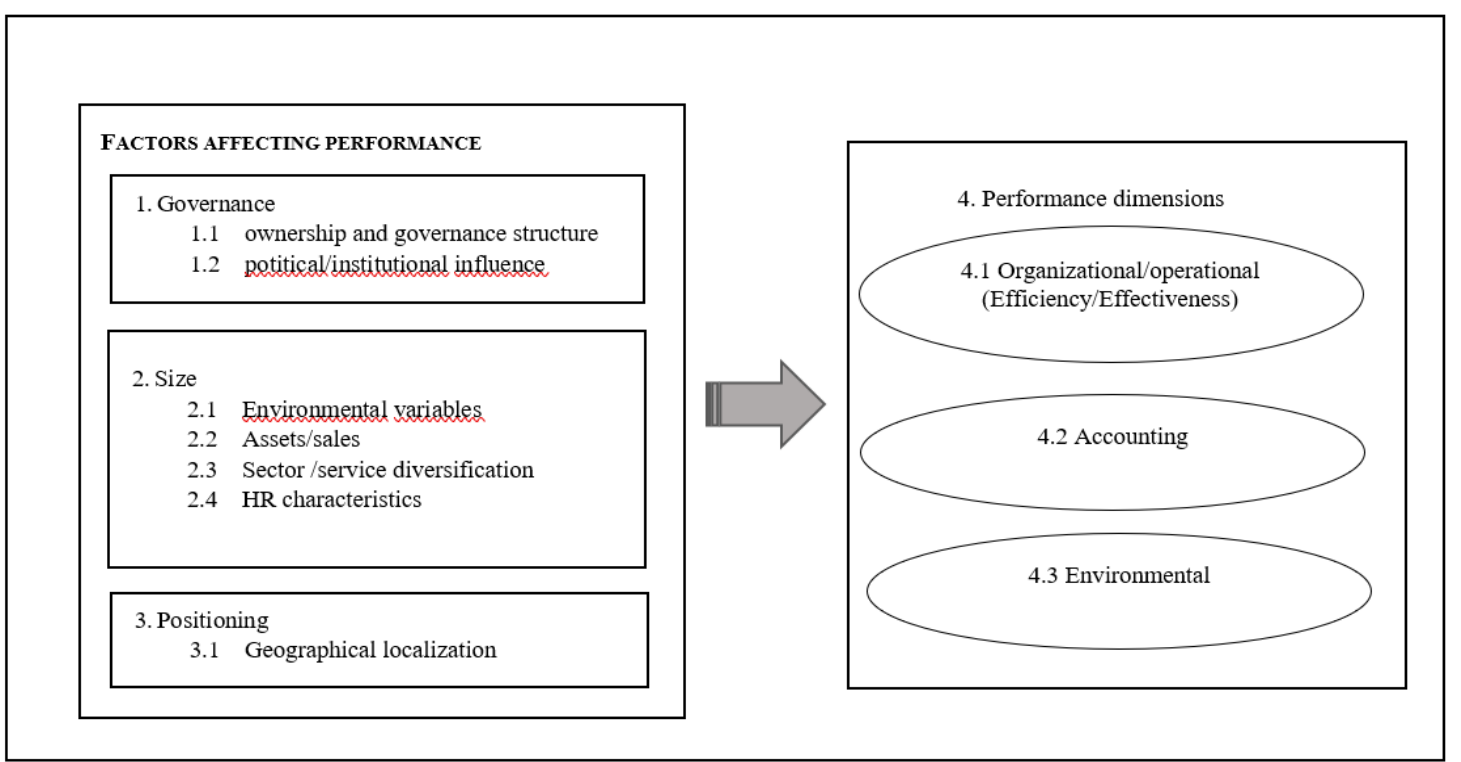

\section{Generated by author}

Figure 2. Literature review clusters

The previous clustering process was used to conduct the subsequent literature review. Thereby, each sampled article has been classified across the four categories within the Table III, focusing on factors affecting utility performance and performance dimensions. In particular, for each analyzed article, a marker (1) shows the sub-category and the performance dimension considered.

Table 3. Sample clustering

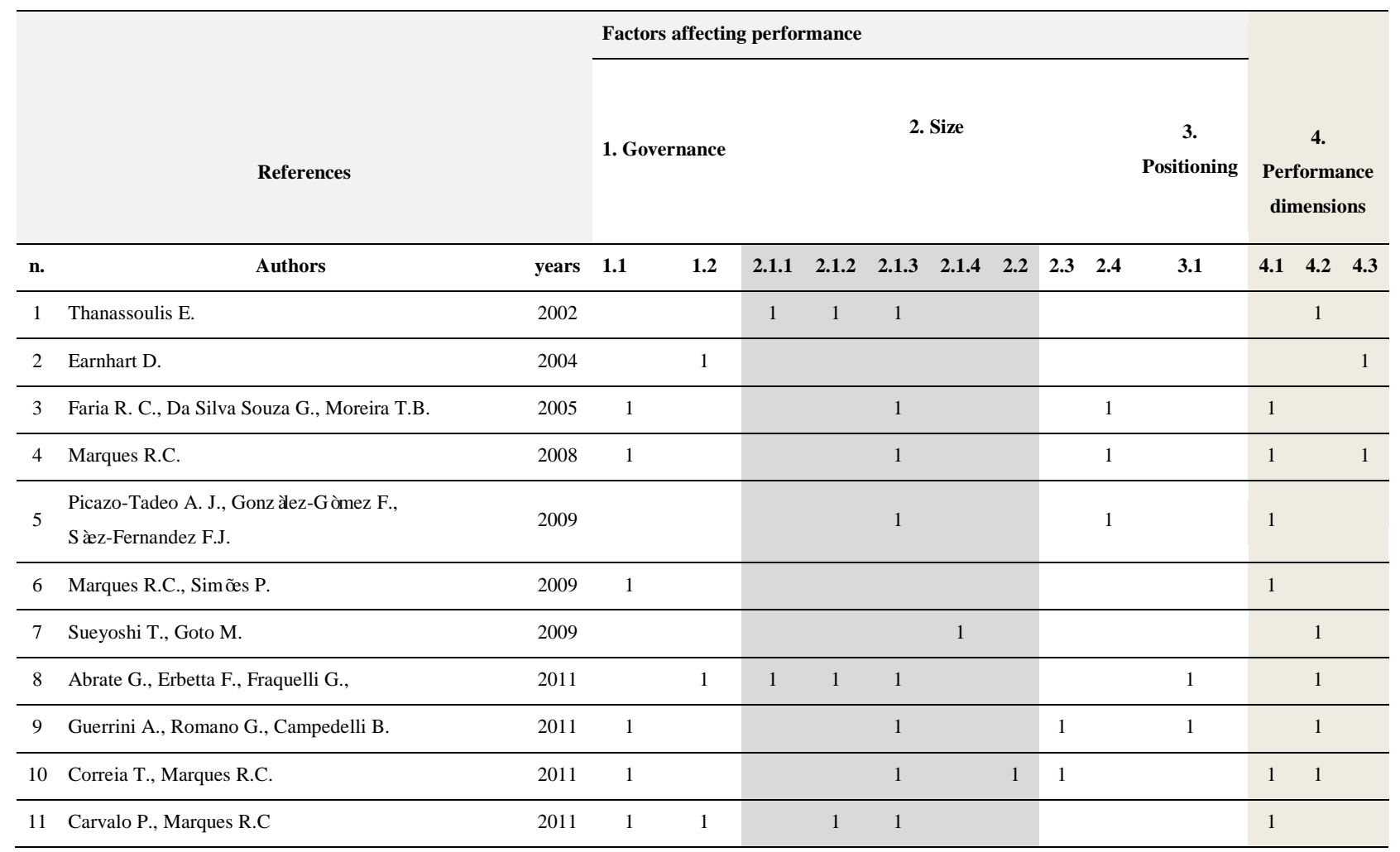




\begin{tabular}{|c|c|c|c|c|c|c|c|c|c|c|c|c|c|c|c|}
\hline 12 & Simões P., Marques R.C & 2011 & 1 & 1 & & & 1 & & & & & & 1 & & \\
\hline 13 & Simões P., Cruz N. F.,Marques R.C. & 2012 & 1 & & & & 1 & & & & 1 & & 1 & & \\
\hline 14 & Mbuvi D., De Witte K., Perelman S. & 2012 & & 1 & & & 1 & & & & 1 & 1 & 1 & & \\
\hline 15 & Abbott M., Cohen B., Chun Wang W. & 2012 & & & & & 1 & & & & & 1 & 1 & & \\
\hline 16 & Gupta S., Kumar S., Sarangi G.K. & 2012 & & & & 1 & 1 & & & & & & 1 & & \\
\hline 17 & Menozzi A., Urtiaga M.G., Vannoni D. & 2012 & & 1 & & & & & & & & & & 1 & \\
\hline 18 & $\begin{array}{l}\text { Yusuf Y.Y., Gunasekaran A., Musa A., El-Berishy } \\
\text { N.M., Abubakar T., Ambursa H. M. }\end{array}$ & 2013 & & & & & 1 & & & & 1 & & 1 & 1 & \\
\hline 19 & Muehlenbachs L., Cohen M.A., Gerarden T. & 2013 & & & & & 1 & & & & & & & & 1 \\
\hline 20 & Peda P., Grossi G., Liik M. & 2013 & 1 & & & 1 & & & & & & & 1 & & \\
\hline 21 & Anestina A. I., Adetola A., Odafe I. B. & 2014 & & 1 & & 1 & 1 & & & & & & 1 & & \\
\hline 22 & Monteduro F. & 2014 & 1 & & & & & & 1 & 1 & & 1 & & 1 & \\
\hline 23 & Romano G., Guerrini A. & 2014 & 1 & 1 & & 1 & & & 1 & & 1 & & & 1 & \\
\hline 24 & Ding S., Jia C., Wu Z., Zhang X. & 2014 & 1 & 1 & & & & & & & & & & 1 & \\
\hline 25 & Sarr B. & 2015 & & 1 & & 1 & 1 & & & & & 1 & 1 & & \\
\hline 26 & Padfield R, Tham M.H., Costes S., Smith L & 2016 & & 1 & & & & & & & & 1 & 1 & 1 & \\
\hline 27 & $\begin{array}{l}\text { Guerrini A., Carvalho P., Romano G., Marques } \\
\text { R.C.Leardini C. }\end{array}$ & 2017 & & & & 1 & 1 & & & & & & 1 & & \\
\hline 28 & Bobde S. M. \& Tanaka M. & 2018 & & 1 & & & 1 & & & & 1 & & 1 & & \\
\hline
\end{tabular}

Generated by author

\section{Literature Analysis}

This section presents the analysis of the literature sample on the basis of the categories previously identified.

1. Governance. With reference to ownership and governance structure (sub-category 1.1) many scholars focus their research on the different impacts on performance between private, public or mixed ownership. Guerrini et al. (2011) claim that "public-owned companies apply lower tariffs, invest more and are more efficient in the use of labor than mixed utilities. On the contrary, privately owned utilities are more oriented toward profit, since their financial ratios are twice those of publicly owned companies, and financial leverage is intensively used". Correia and Marques (2011) confirm that the private companies present a higher level of efficiency compared with the publicly owned utilities. Also Monteduro (2014) reveals that the presence of private shareholders may lead to a better degree of a utility's profitability and efficiency. Faria et al. (2005) highlight that private companies are only marginally more efficient than public ones; while Marques and Simões (2009) find no difference in efficiency between the private and public solid waste services. Similarly, Carvalo and Marques (2011) find that private/public ownership does not influence the production process in the water utilities.

Simões et al. (2012) focus on utility management models in terms of autonomy, highlighting different levels of inefficiency among them. The authors conclude that municipal companies have the best performance, probably as a consequence of their higher level of autonomy.

The literature on board composition highlights how board diversity, age, experience and political connection can influence an organization's performance, although the empirical findings are not unanimous. Besides, gender diversity may improve board variety and deliberation (Erhardt et al. 2003).

In their research, Romano and Guerrini (2014) show "that board composition, in terms of the age and educational background of members, influences economic performance, since graduate and senior directors exert a negative influence on profitability". The authors also consider the presence and percentage of women on boards of directors to 
take into account the possibility of a relationship between gender diversity and firm performance. They conclude that the percentage of female board members affects neither economic nor financial indicators.

Governance is also analyzed in terms of the political connection of the board of directors and in terms of institutional influence on utility activity played by upper levels of authority through issuing regulation (sub-category 1.2).

Menozzi et al. (2012), focusing on board composition, carry out an analysis based on political affiliation, autonomy and status both of insider and outsider directors. The authors state that "politically connected directors may be identified by their present or past activity in the political arena, as represented by a political appointment, the membership to a political party, or the candidacy for election". The main findings of their research indicate that politically connected directors exert a negative impact on performance.

Romano and Guerrini (2014) consider the "politically connected directors, examining whether or not each director on the board held or had held political assignments, candidacies in national and local elections, and/or membership of a political party". The authors conclude that politically connected directors boost access to debt and negatively affect the firms' capital structures.

Ding et al. (2014), adopt two categories of independent variables impacting performance: the political influence of ownership - assessed on the basis of the nature of a utility's final control - and the political influence of management - in the form of the political connections of individual executives such as the board chairs and the CEO. In the context of state-controlled ownership that is typical in publicly listed Chinese companies, the authors find that the political influence of ownership significantly deteriorates the effectiveness of corporate governance mechanisms by reducing the proportion of independent directors.

Anestina et al. (2014) analyze the impact on performance coming from institutional influence that is considered as the adherence to regulatory arrangement. They find that the adherence to regulatory arrangement is a factor that positively influences productivity performance. The authors argue that, in order to enhance effective productivity, all private operators in the sector of utility, should strictly adhere to the regulatory arrangements and policies governing the activity.

Earnhart (2004) examines the impact of regulatory factors (permit conditions, inspections, enforcement actions) on environmental performance in the wastewater sector. The author finds that these factors induce better environmental performance. According to Carvalho and Marques (2011) regulation has a positive influence on the efficiency of water service utilities.

Sarr's findings (2015) support the idea that the establishment of an Independent Regulation Authority in the electricity sector delivers some planned outcomes. It improves the technical quality of electricity service: the reduction of electricity power losses, the increase of the average electricity generated; while the impact on energy efficiency (measured by gross domestic product per unit of energy used) is also positive but insignificant.

Padfield et al. (2016) analyze the impact on the performance of water utilities generated by the regulation. Their research is focused on the impact on the performance of water utilities generated by the Water policy reforms introduced in Peninsular Malaysia in 2008. It is the 'asset light policy' - a policy with the aim of commercializing public water utilities and centralizing the water sector investment and ownership. It is found that notwithstanding evidence of improved financial health and technical efficiency in certain states, the asset light policy has accentuated uneven water development across the country.

Abrate et al. (2011) study the impact of decentralized regulation on the cost efficiency of the water service. The results indicate that in the Italian water and sewerage industry regulation failed to fulfill the declared goal applying a decentralized planning mechanism. The authors also highlight that the time-invariant terms are the prevailing source of cost differences, which may mask a structural component attributable to persistent inefficiency.

According to Abbot et al. (2012), policy makers should take into account the impact of pricing regulation on subsequent utility performance. They conclude that "the dissipation of productivity growth could have been caused by different factors including the tendency for companies to shift emphasis from improving productivity growth to managing water, the higher costs involved in pumping and transporting water from depleted stocks, and the lack of competition after the reforms that would further pressure companies to improve productivity".

Bobde and Tanaka (2018) consider, among the variables affecting performance of utilities active in the electricity distribution sector in India, the subsidy amount provided by the government to distribution utilities. The government's policies define the amount of subsidies, especially those addressed to agricultural users and domestic 
customers in rural areas. Finally, the authors find a negative relation between government subsidies and utility efficiency.

2. Size. The environmental variables (2.1) in the sampled literature are usually related to the operating context of the utilities.

According to Thanassoulis (2002) the served territory (sub-category 2.1.1) is highly correlated to operating expenditure savings. In the sewerage sector services, the length of the sewer network is one of the most important drivers of operating expenditure.

The served population (sub-category 2.1.2) is also highly correlated to operating expenditure savings.

Gupta et al. (2012) consider the variable of the percentage of the population served which, in their research, indicates the proportion of the population in the service area who receive water from the public water system, compared to the total population of the city. The analysis confirms that less populated cities perform relatively better and have better overall technical efficiency scores. Moreover, the decomposition of technical efficiency results suggests that less populated cities have higher scale efficiency in contrast to the other group, which performs better in terms of pure technical efficiency. On the contrary, Peda et al. (2013) find that small water companies (in terms of population served) are significantly less efficient than those of a medium or large size.

Guerrini et al. (2017) consider different factors affecting performance: customer features (population density, size of population served, percentage of non-residential customers and tourist flows) and household features (measured by number of inhabitants per house). The influence of population density on the efficiency of utilities shows a variable trend. The effect tends to be negative in some ranges of population density values. Similarly, Carvalho and Marques (2011) find that there is a negative influence up to 50 customers per $\mathrm{km}$, while there is approximately a null influence to higher customer densities.

Much of the literature related to the productivity of utilities is contextualized in the water industry and shows some disagreements regarding the definition of the technical characteristics of the service (sub-category 2.1.3) and the way in which they should be measured. Often the choice of approach is not determined by the relative merits of either approach, but, instead, by the availability of data.

Correia and Marques (2011) consider the entity of water loss and conclude that the smaller the volume of water loss, the lower the cost of the water utility. In the same sector, the size category is also analyzed in terms of amount of water billed in cubic meters: "there is a higher probability of finding diseconomies of scale and scope in large utilities, although statistical significance was only found for scale diseconomies" (Carvalho et al., 2012).

According to Simões and Marques (2011), the environmental variables in the waste sector represented by the distance to treatment facilities and the existence of organic valorization plants, negatively impacts on utilities efficiency.

Simões et al. (2012), analyzing waste sector performance, consider vehicles and other operational expenditures and the results point out the inefficiency induced by scale diseconomies.

Mbuvi et al (2012) find that network density correlates positively to utility technical efficiency but negatively influences utility effectiveness.

Picazo-Tadeo et al. (2009) argue that "the delivery network quality exercises a negative and statistically significant effect on slacks in operational costs. In other words, operational costs are lower for water utilities with delivery networks of worse quality".

Gupta et al. (2012), when considering the technical characteristics of the service, take into account: 1) water connections per 1,000 inhabitants that highlight significant variations across cities; 2) mean hours of water supply that indicates the average hours of water supply from the public system in a city. The authors conclude that the sampled cities show a very poor performance.

Other technical characteristics that affect the utility performance are estimated in the sector of waste management. Some authors consider years of operation, number of vehicles used, average number of times trucks are serviced per month, number of daily trips (Anestina et al. 2014); tons of waste collected for each load, method adopted (curbside or street bin), and maturity achieved with a given method (Guerrini et al. 2017). Regarding electricity service some technical indicators are: electricity generation per capita, electrical power transmission and distribution losses, and gross domestic product per unit of energy use (Sarr, 2015). 
With relation to the offshore oil and gas production, Muehlenbachs et al. 2013 find that the technical characteristics of the service (such as distance to shore, age and number of platforms managed by the operator) are related to incidents on platforms. The Authors suggest, "that the enforcement agencies might consider these factors in designing targeted inspection programs".

Analyzing the US electric utility firms, Sueyoshi and Goto (2009) investigate the impact of environmental investment and expenditure (2.1.4) on financial performance. In particular, the authors quantify the environmental effort in terms of environmental investment (considering the long-term) in protection facilities and environmental protection cost (considering the short-term) that is the ratio between annual expenditure for environmental protection and the total operating revenue.

To evaluate the impact of utility size on their performance, literature also refers to indicators represented by assets (sub-category 2.2). With reference to this dimension, Monteduro (2014) states that the size of the organization (logarithm value of total assets) can affect economic and financial performance. In particular total assets negatively affect ROA (Return on Asset) and ROI (Return on Investment), as highlighted by Romano and Guerrini (2014).

With reference to the to sub-category 2.3 (sector of activity and/or service diversification) Monteduro (2014) analyzes the impact of sector of activity on the utility performance and states that the field of activity (water, waste, gas, energy, transport, pharmacy or other), and the related regulatory framework affect economic performance.

According to Guerrini et al. (2011), the results show that multi-utilities have a higher return on sales and capital turnover than the mono-utilities. While Correira and Marques (2011) consider service diversification and find that utilities that provide only the water supply service have the highest average level of efficiency, with a very small difference from the lowest average efficiency level presented by the utilities that offer more than one service.

With reference to the human resource characteristics (sub-category 2.4), Picazo-Tadeo et al. (2009) and Simões et al. (2012) consider the number of full-time employees and find that labor is one of the main production factors affecting efficiency. In particular, private utilities outperform public companies in the management of this specific production factor.

3. Positioning. This category refers to geographical localization (sub-category 3.1). A reference to geographical localization is present in Guerrini et al. (2011). They confirm that there are significant differences among water utilities located in different geographical areas. Their study considers the Italian territory and finds that the utilities of the sample located in the north are more oriented toward their customers, applying low tariffs and making more investments; those operating in the center show higher tariffs and fewer investments to cut overhead costs, so they are more oriented toward profit. Finally, the utilities located in the south of the country highlight more contrasting results.

According to Monteduro (2014), who analyzes Italian local utilities, the socio-economic environment of a specific geographical location may significantly affect economic performance. In particular, utilities operating in Central and, above all, in Southern Italy, may record a lower economic performance, due to the fact that they operate in less developed socio-economic environments.

4. Performance dimensions. The literature analysis reveals that the authors of the sampled articles attribute different meanings to the concept of performance, which can be grouped into three main dimensions: organizational/operational, accounting and environmental.

With reference to the organizational/operational performance (sub-category 4.1), Simões et al. (2012) analyze the effects on efficiency and productivity (considered as the relationship between the output produced and the input consumed), while Mbuvi et al. (2012) focus on performance as technical efficiency and effectiveness. The authors define technical efficiency comparing the physical output expansion with employed physical inputs. They state that utility effectiveness reflects the extent to which sector objectives are met, obtaining both a maximal output with the given resources (efficiency) and the satisfaction of their customer needs (effectiveness).

According to Faria et al. (2005), performance as technical efficiency is measured by estimating a production function that considers capital, labor and productivity; while Anestina et al. (2014) assess the performance using productivity analysis and quality of service.

Marques (2008), assessing performance indicators, observes that private ownership presents better performance in terms of water quality, water loss and personnel.

Regarding the impact on accounting performance (sub-category 4.2), the main factors analyzed are profitability, investments, tariffs, efficiency, financial leverage (Guerrini et al., 2011) and operating expenditure savings 
(Thanassoulis, 2002). Some authors (Menozzi et al., 2012; Monteduro, 2014) adopt indicators commonly used in financial statement analyses, such as: Return on Investment (ROI), which measures the profitability and efficiency of an enterprise's core business, regardless of the sources of financing; Return on Equity (ROE), which measures the rate of return on the ownership interest; Return on Sales (ROS), which is used to evaluate a company's operational efficiency. In other words, the ratio expresses how efficiently management uses sales revenues, thus reflecting its ability to manage costs and overhead and operate efficiently.

Romano and Guerrini (2014) consider other indicators arising from accounting system values: debt to equity ratio, financial autonomy, net financial position and Return on Assets (ROA). Ding et al. (2014) also consider the latter index.

Only three articles consider both the organizational/operational and the accounting dimensions of performance. Correia and Marques (2011) consider performance as service accessibility, the quality of service supplied to users, economic and financial sustainability, infrastructural sustainability, operational sustainability and human resource sustainability.

Yusuf et al. (2013) analyze performance using measures related both to organizational performance (e.g. flexibility, innovation, etc.) and to financial performance (e.g. sales turnover). Padfield et al. (2016) adopt non-revenue water as a proxy of operational and financial performance since it indicates how efficiently utilities are distributing treated water to consumers and obtaining revenue in return.

With reference to the environmental dimension of the performance (sub-category 4.3), it is interesting to highlight that only in one article sampled, is there an analysis that considers this dimension. Marques (2008), comparing private and public performance of the Portuguese water service, identifies "water losses" as an indicator that can be clustered in the environmental dimension of performance. He concludes that private ownership of water utilities has a better performance also in terms of water loss, than public ownership.

Earnhart (2004), examining the impact of regulatory factors on environmental performance, considers it as biological oxygen demand wastewater discharges by large municipal wastewater treatment plants. He finds that this environmental indicator is positively affected by regulatory factors (e.g. inspections).

Another aspect analyzed in the environmental dimension of performance is represented by the number of incidents (e.g. oil spills) occurring in offshore oil and gas production (Muehlenbachs et al. 2013). The authors find that incidents are correlated to water depth. In particular, the probability of an incidents being reported increases the deeper the water.

\section{Discussion}

In order to answer R.Q. 1 ("What factors affect utility performance and what is the role of environmental variables?") we systematically analyzed the literature sample.

Governance was analyzed considering ownership and governance structure, political and/or institutional influence. In general, scholars claim that private ownership leads to better utility performance (e.g. Guerrini et al., 2011; Correia and Marques; 2011). At the same time, a reflection is needed on the independence of management: autonomy has a good impact on performance (Simões et al. 2012). With regard to the composition of the board of directors, senior directors exert a negative influence on profitability (Romano and Guerrini, 2014). It is interesting to highlight that in all the papers analyzed, there is unanimous conclusion on the negative impact that political connections have on utility performance (e.g. Menozzi et al. 2012; Ding et al., 2014). In our opinion, this represents a relevant criticism, because utility autonomy in light of political influence is difficult for at least two reasons. The first is that these organizations supply a public service with specific regulation that is a political influence factor. The second is that utilities are often publicly owned, so, in this case, the political body represents the ownership; consequently, avoiding its influence is practically impossible.

Literature on institutional influence, considered in terms of regulation impact, appears ambiguous. Some authors (Anestina, 2014; Sarr, 2015; Padfield et al., 2016) find a positive influence on organizational/operational and accounting performance dimensions. Others (Abrate et al., 2011; Abbot et al., 2012) depict a negative impact of regulation on performance. A specific field of political/institutional influence is represented by the subsidies provided by the government to utilities. Bobde and Tanaka (2018) find that government subsidies are negatively related to the efficiency of the utilities. This allows us to underline the importance of the government's role, which, on the one hand, should support utility activities because of their public impact, and, on the other hand, should also pay attention to efficiency and effectiveness that subsidies could limit. 
Size was divided into four components represented by environmental variables (territory served, population/customers served, technical characteristics of the service, environmental investment/expenditure), assets/sales, sector/service diversification and human resource (HR) characteristics.

With reference to the role attributed by scholars to the environmental variables, the analysis carried out highlights the use of these kinds of variables and their impact on the efficiency and accounting performance of utilities. For example, Yusuf et al. (2013) assert that "It has also been possible to reduce the use of resources such as water and to encourage the recycling of waste as much as possible. Therefore, it can be concluded that these measures go a long way in limiting waste along the supply chain and, hence, in saving the companies money".

However, variables are often identified as "environmental" but in the sense of "context variables" (e.g. waste collecting method, age and number of platforms managed in the oil and gas sector, subsidies, consumer structure, gross domestic product, etc.). Among these variables, the selected literature is more oriented to analyzing the technical characteristics of the service.

We found conflicting conclusions related to sector/service diversification. Some authors (Guerrini et al., 2011) state that multi-utilities have better performance than mono-utilities, while others (Correira and Marques, 2011) find that mono-utilities have the highest average level of efficiency.

With reference to the impacts of the factors related to the size category, all the sub-categories analyzed by the authors have an impact on utility efficiency. Furthermore, the literature analyzing size factors is prevalently focused on water and waste management services, so it could be interesting to understand if the same conclusions (relationship between size and performance) can also be found for other fields of utility activity.

Positioning was considered to be geographical localization. The analyzed literature pays less attention to this factor. With reference to geographical localization, authors agree that there are significant differences among utilities operating in different territories.

With reference to R.Q. 2: "What are the performance dimensions investigated and what attention is paid to the environmental dimension?" three dimensions of performance (influenced by the factors analyzed through quantitative methods in the sampled literature on the utility sector) are clustered: organizational/operational, accounting and environmental.

The organizational/operational performance dimension is the most investigated and it is considered in terms of efficiency and productivity, effectiveness, service quality, flexibility and innovation.

The accounting performance dimension received less attention in literature compared to the organizational/operational performance dimension. The accounting evidence of performance is investigated in terms of ROI, ROE, ROS, operating expenditure savings and net financial position.

It is interesting to highlight that, in analyzing the impact of ownership and governance structure on performance, scholars take into consideration its operational dimension and not the accounting one which, typically, is of greater interest for ownership and governance.

With regard to the attention paid to the environmental performance, while, in general, this concept is widely examined in literature (Shultz and Trommer, 2012) - especially in terms of environmental performance measurement - less attention to this performance dimension was detected in the literature sampled in this study. In other words, in analyzing the factors affecting utility performance using quantitative research methods, the scholars focus their attention on the impact on organizational/operational and accounting performance. Only in three articles, the impact on environmental performance is investigated and this performance dimension is considered in terms of water loss, oil and gas platform incidents and biological oxygen demand wastewater discharges.

\section{Conclusion}

The privatization of public services, affecting many countries all over the world, depends on the search for better performance. A particularly relevant aspect of the utility activities is represented by their connection to the environment (Muehlenbachs et al. 2013). Therefore, many works on performance assessment have been published and specific attention is given to identify what factors affect the performance of utilities and what performance dimensions have been identified by the scholars.

But, prior literature on the utility sector lacked a systematic understanding of the different factors affecting performance with a specific consideration of the environmental sphere. Consequently, this paper contributes to the theme of utility management trying to bridging this literature gap developing a literature review that provides: 
- a clusterization useful to systematize the factors affecting utility performance;

- a focus on the environmental sphere both in terms of factors affecting performance and in terms of performance dimensions.

Therefore, the research develops a literature review focusing on studies using quantitative research methods, in order to highlight: (1) the factors affecting the different dimensions of utility performance and the role given to the environmental sphere (RQ1 and RQ2), also suggesting further research development; (2) managerial implications deriving from point 1.

With reference to the point 1 , the proposed clusterization scheme (Fig. II) can be useful both to highlight the environmental sphere and to identify a research reference scheme for further studies (considering the width and the complexity of the analyzed topic).

Regarding the environmental factors affecting utility performance, it should be noted that the meaning that the literature attributes to "environmental variables" is often related to the operating context of the utilities. Consequently, we suggest the development of studies that consider environmental variables effectively related to the "green sphere" (e.g. the use of natural resources, the use of renewable energies, investments in clean technology, etc.). This can help scholars to better understand the impact of the environmental sphere on different performance dimensions.

Regarding environmental dimensions of the utility performance, literature has expanded - also by virtue of the legislation in force - but it is still mainly focused on performance measurement (Hopkinson et al., 2000; Ku-Pineda and Tan, 2006; Williams and Kahrl, 2008) and environmental reporting (Mio, 2010; Silva-Gao, 2012).

The analysis of the literature presented here shows a lack of studies that deepen the relationship between factors of influence and environmental performance of utilities. Consequently, this aspect needs the development of variables that identify the environmental dimension of performance (D'Inverno et al., 2021). In other words, few works have emerged that investigate the influence on the environmental dimension (category 4.3 of Fig. II) of various impact factors.

For example, it might be interesting to develop quantitative research to analyze:

- whether (together with other variables of various nature) the maintenance costs of water systems and the number of maintenance interventions of the same in relation to the length of the network have an influence on the liters of water loss (environmental performance);

- whether the different ways of waste collection can have an impact on the percentage of separate collection (environmental performance).

This also suggests the usefulness of qualitative research papers addressed to identify environmental variables to be used in quantitative works.

From a managerial point of view (point 2), the analysis first shows the need for independence in utility management (Simoes et al., 2012) considering that the political influence has a negative impact on utility performance. From this, a reflection on the management appointing strategy arises: if managers are selected based on their skills (and not based on political connection), probably, they are more independent (with positive impact on the performance) and not strictly embedded in the political vision focused on consensus. Consequently, from an environmental point of view, the appointment of managers should considers their "green skills" as an important factor that could lead to better environmental performance of the utilities. Therefore, a managerial fallout is represented by the need for adequate managerial skills (Angiola and Bianchi, 2015). Regarding this aspect, our analysis also revealed that directors' seniority has a negative impact on performance, so this suggests it may be appropriate to appoint younger managers that, probably, could be more aware about environmental issues (Kundu \& Thakur, 2006). Furthermore, utility management, especially considering the kind of services supplied, should gather information about manager's ability to face collective needs. So we claim that managers should consider customer satisfaction and service quality (Pinto et al., 2017) as a further dimension of performance.

Secondly, our analysis highlights that, on the one hand, there are many categories of factors affecting utility performance; and, on the other hand, that their influence can sometimes be positive and in other cases be negative. From this complexity, managers need to be continuously attentive to monitoring factors affecting performance. In other words, among the managerial implications, our literature review reveals the need to develop managerial tools to make the decision-making process effective and efficient in order to guide them to better performance 
management control systems (Di Vaio et al., 2019), especially in the environmental sphere. This is also helpful to support the development of future business "green" strategies.

In this regard, among the factors that can influence utility performance (categories 1, 2 and 3 of Fig. II), the analysis carried out highlights the absence of variables such as the use of managerial tools. As an example, it could be interesting to consider if the use of environmental accounting has an impact on one or more dimensions of utility performance.

\section{References}

Abbott, M., Cohen B., \& Chun Wang W. (2012). The performance of the urban water and wastewater sectors in Australia. Utilities Policy, 20(1), 52-63. https://doi.org/10.1016/j.jup.2011.11.003

Abrate, G., Erbetta, F., \& Fraquelli, G. (2011). Public Utility planning and cost efficiency in a decentralized regulation contest: The case of the Italian integrated water services. Journal of Productivity Analysis, 35(3), 227-242. https://doi.org/10.1007/s11123-010-0192-0

Adams, R. B., Hermailin, B. E., \& Weisbach, M. S. (2010). The role of boards of directors in corporate governance: a conceptual framework and survey. Journal of Economic Literature, 48(1), 58-107. Retrieved from www.jstor.org/stable/40651578

Ait Sidhoum, A., \& Serra, T. (2017). Corporate social responsibility and dimensions of performance: An application to U.S. electric utilities. Utilities Policy, 48, 1-11. https://doi.org/10.1016/j.jup.2017.06.011

Anestina, A. I., Adetola, A., \& Odafe, I. B. (2014). Performance Assessment of Solid Waste Management following Private Partnership Operations in Lagos State, Nigeria. Journal of Waste Management, 1-8. https://doi.org/10.1155/2014/868072

Angiola, N., \& Bianchi, P. (2015). Public Managers' Skills Development for Effective Performance Management: Empirical Evidence from Italian Local Governments. Public Management Review, 17(4), 517-542. https://doi.org/10.1080/14719037.2013.798029

Beecher, J. (2013). What matters to performance? Structural and institutional dimensions of water utility governance. International Review of Applied Economics, 27(2), 150-173. https://doi.org/10.1080/02692171.2012.752447

Benito, B., Del Rocio Moreno, M., \& Solana, J. (2011). Determinants of efficiency in the provision of municipal street-cleaning and refuse collection services. Waste Management, 31(6), 1099-1108. https://doi.org/10.1016/j.wasman.2011.01.019

Berg, S., \& Marques, R. (2011). Quantitative studies of water and sanitation utilities: a benchmarking literature survey. Water Policy, 13, 591-606. https://doi.org/10.2166/wp.2011.041

Bobde, S. M., \& Tanaka, M. (2018). Efficiency evaluation of electricity distribution utilities in India: A two-stage DEA with bootstrap estimation. Journal of the Operational Research Society, 69(9), 1423-1434. https://doi.org/10.1080/01605682.2017.1398202

Calabrò A., Torchia, M., \& Ranalli F. (2013). Ownership and control in local utilities: the Italian case. Journal of Management and Governance, 17(4), 835-862. https://doi.org/10.1007/s10997-011-9206-1

Carvalho, P., \& Marques, R. C. (2011). The influence of the operational environment on the efficiency of water utilities. Journal of Environmental Management, 92, 2698-2707. https://doi.org/10.1016/j.jenvman.2011.06.008

Carvalho, P., Marques R. C., \& Berg, S. (2012). A meta-regression analysis of benchmarking studies on water utilities market structure. Utilities Policy, 21, 40-49, https://doi.org/10.1016/j.jup.2011.12.005

Cetrulo, T. B., Ferreira, D. F. C., Marques, R. C., \& Malheiros, T. F. (2020). Water utility performance analysis in development countries: on an adequate model for universal access. Journal of Environmental Management, 268. https://doi.org/10.1016/j.jenvman.2020.110662

Correia, T., \& Marques, R. C. (2011). Performance of Portuguese water utilities: how do ownership, size, diversification and vertical integration relate to efficiency?. Water Policy, 13(3), 343-361. https://doi.org/10.2166/wp.2010.032

D’Inverno, G., Carosi, G., \& Romano, G. (2021). Environmental sustainability and service quality beyond economic and financial indicators: A performance evaluation of Italian water utilities. Socio-Economic Planninig Sciences, 75. https://doi.org/10.1016/j.seps.2020.100852 
DeWenter, K. L., \& Malatesta, P. H. (2001). State-owned and privately owned firms: An empirical analysis of profitability, leverage, and labor intensity. American Economic Review, 91(1), 320-334. https://doi.org/10.1257/aer.91.1.320

Di Vaio, A., Varriale, L., \& Trujillo, L. (2019). Management Control Systems in port waste management: Evidence from Italy. Utilities Policy, 56, 127-135. https://doi.org/10.1016/j.jup.2018.12.001

Ding, S., Jia, C., Wu, Z., \& Zhang, X. (2014). Executive political connections and firm performance: comparative evidence form privately-controlled and state-owned enterprises. International Review of Financial Analysis, 36(C), 153-167. https://doi.org/10.1016/j.irfa.2013.12.006.

Earnhart, D. (2004). Regulatory factors shaping environmental performance at publicly-owned treatment plants. Journal of Environmental Economics and Management, 48, 655-681. https://doi.org/10.1016/j.jeem.2003.10.004

Ehrhardt, D., \& Janson, N. (2010). Can regulation improve the performance of government-controlled water utilities?. Water Policy, 12, 23-40. https://doi.org/10.1142/9789814335744_0013

Eloranta, V., \& Turunen, T. (2015). Seeking competitive advantage with service infusion: a systematic literature review. Journal of Service Management, 26(3), 394-425. https://doi.org/10.1108/JOSM-12-2013-0359.

Ensslin, S. R., Ensslin, L., dos Santos Matos, L., Dutra, A., \& Ripoll-Feliu, V. M. (2015). Research opportunities in performance measurement in utilities regulation. International Journal of Productivity and Performance Management, 64(7), 994-1017. https://doi.org/10.1108/IJPPM-05-2014-0067.

Erhardt, N. L., Werbel, J. D., \& Shrader, C. B. (2003). Board of director diversity and firm financial performance. Corporate Governance International Review, 11, 102-111. https://doi.org/10.1111/1467-8683.00011

Faria R. C., Da Silva Souza G., \& Moreira T. B. (2005). Public Versus Private Water utilities: Empirical Evidence for Brasilian Companies. Economics Bulletin, 8(2), 1-7. Retrieved from RePEc:ebl:ecbull:eb-05h00001

Filbeck, G., \& Gorman, R. F. (2004). The relationship between environmental and financial performance of public utilities. Environmental and Resouce Economics, $29, \quad$ 137-157. https://doi.org/10.1023/B:EARE.0000044602.86367.ff

Florentin, D. (2019). From multi-utility to cross-utilities: the challenge of cross-sectoral entrepreneurial strategies in a German city. Urban Studies, 56(11), 2242-2260. https://doi.org/10.1177/0042098018798974

Guerrini, A., Carvalho, P., Romano, G, Marques, R. C., \& Leardini, C. (2017). Assessing efficiency drivers in municipal solid waste collection services through a non-parametric method. Journal of Cleaner Production, 147, 431-441. https://doi.org/10.1016/j.jclepro.2017.01.079

Guerrini, A., Molinos-Senante, M., \& Romano, G. (2018). Italian regulatory reform and water utility performance: An impact analysis. Utility Policy, 52, 95-102. https://doi.org/10.1016/j.jup.2018.03.005

Guerrini, A., Romano, G., \& Campedelli, B. (2011). Factors affecting the performance of water utility companies. The International Journal of Public Sector Management, 24(6), 543-566. https://doi.org/10.1108/09513551111163657

Guerrini, A., Romano, G., \& Campedelli, B. (2013). Economies of Scale, Scope, and Density in the Italian Water Sector: A Two-Stage Data Envelopment Analysis Approach. Water Resources Management, 27(13), 4559-4578. https://doi.org/10.1007/s11269-013-0426-9

Gupta, S., Kumar, S., \& Sarangi G. K. (2012). Measuring the performance of water service providers in urban India: implications for managing water utilities. Water Policy, 14(3), 391-408. https://doi.org/10.2166/wp.2011.109

Hopkinson, P., James, P., \& Sammut, A. (2000). Environmental Performance Evaluation in the Water Industry of England and Wales. Journal of Environmental Planning and Management, 43(6), 873-895. https://doi.org/10.1080/09640560020001737

Hukka, J. J., \& Vinnari, E. M. (2007). Public-public partnerships in the Finnish water services sector, Utilities Policy, 15, 86-92. https://doi.org/10.1016/j.jup.2007.01.002

Koushki, P. A., Al-Duaij, U., \& Al-Ghimlas, W. (2004). Collection and transportation cost of household solid waste in Kuwait. Waste Management, 24(9), 957-964. https://doi.org/10.1016/j.wasman.2004.03.013

Kundu, A., \& Thakur, S. (2006). Access to drinking water in India: an analysis of emerging spatial pattern in the context of new system of governance. In R. V. Reddy, \& S. Mahendra Dev (Eds.), Managing Water Resources, Policies, Institutions and Technologies. Oxford University Press, New Delhi. 
Ku-Pineda, V., \& Tan R. R. (2006). Environmental performance optimization using process water integration and Sustainable Process Index. Journal of Cleaner Production, 14, 1586-1592. https://doi.org/10.1016/j.jclepro.2005.04.018

Landis, A. E. (2015). The State of Water/Wastewater Utility Sustainability: A North American Survey. Journal-American Water Works Association, 107(9), E464-E473. https://doi.org/10.5942/jawwa.2015.107.0125

Marques, R. C. (2008). Comparing private and public performance of Portuguese water services. Water Policy, 10(1), 25-42. https://doi.org/10.2166/wp.2007.033

Marques, R. C., \& Simões, P. (2009). Incentive regulation and performance measurement of the Portuguese solid waste management services. Waste Management Resource, 27(2), 188-96. https://doi.org/10.1177/0734242X08095025

Mbuvi, D., De Witte, K., \& Perelman, S. (2012). Urban water sector performance in Africa: A step-wise bias-corrected efficiency and effectiveness analysis. Utilities Policy, 22, 31-40. https://doi.org/10.1016/j.jup.2012.02.004

Megginson, W., Nash, R., \& Van Randenborgh, M. (1994). The financial and operating performance of newly privatized firms: an international empirical analysis. The Journal of Finance, 49, 403-452. https://doi.org/10.2307/2329158

Menozzi, A., Urtiaga, M. G., \& Vannoni, D. (2012). Board Composition, Political Connections and Performance in State-Owned Enterprises. Industrial and Corporate Change, 21(3), 671-698. https://doi.org/10.1093/icc/dtr055

Mio, C. (2010). Corporate Social Reporting in Italian Multi-utility Companies: An Empirical Analysis. Corporate Social Responsibility and Environmental Management, 17, 247-271. https://doi.org/10.1002/csr.213

Monteduro, F. (2014). Public-private versus public ownership and economic performance: evidence from Italian local utilities. Journal of Management \& Governance, 18(1), 29-49. https://doi.org/10.1007/s10997-012-9235-4

Muehlenbachs, L., Cohen, M. A., \& Gerarden, T. (2013). The impact of water deep on safety and environmental performance in offshore oil and gas production. Energy Policy, 55, 699-705. https://doi.org/10.1016/j.enpol.2012.12.074

Osborne, S., \& Brown, K. (2005). Managing Change and Innovation in Public Service Organizations. Routledge, London.

Padfield, R., Tham, M. H., Costes, S., \& Smith, L. (2016). Uneven development and the commercialisation of utilities: A political ecology analysis of water reforms in Malaysia. Utilities Policy, 40, 152-161. https://doi.org/10.1016/j.jup.2016.02.003

Parker, D. (2003). Performance, risk and strategy in privatised regulated industries. The UK's experience. The International Journal of Public Sector Management, 16(1), 75-100. https://doi.org/10.1108/09513550310456436

Passarini, F., Vassura, I., Monti, F., Morselli, L., \& Villani, B. (2011). Indicators of waste management efficiency related to different territorial conditions. Waste Management 31(4), 785-792. https://doi.org/10.1016/j.wasman.2010.11.021

Peda, P., Grossi, G., \& Liik, M. (2013). Do ownership and size affect the performance of water utilities? Evidence from Estonian municipalities. Journal of Management and Governance, 17, 237-25. https://doi.org/10.1007/s10997-011-9173-6

Picazo-Tadeo, A. J., Gonzàlez-Gòmez, F., \& Sàez-Fernandez, F. J. (2009). Accounting for operating environments in measuring water utilities'managerial efficiency, The Service Industries Journal, 29(6), 761-773. https://doi.org/10.1080/02642060802190300

Picazo-Tadeo, A. J., Sàez-Fernandez, F. J., \& Gonzàlez-Gòmez, F. (2008). Does service quality matter in measuring the performance of water utilities?. Utilities Policy, 16, 30-38. https://doi.org/10.1016/j.jup.2007.10.001

Pinto, F. S., Simões, P., Marques, R. C. (2017). Water services performance: do operational environment and quality factors count?. Urban Water Journal, 14(8), 773-781. https://doi.org/10.1080/1573062X.2016.1254254

Romano, G., \& Guerrini, A. (2014). The effects of ownership, board size and board composition on the performance of Italian water utilities. Utilities Policy, 31, 18-38. https://doi.org/10.1016/j.jup.2014.06.002 
Ruhlandt, R. W. S. (2018). The governance of smart cities: A systematic literature review. Cities, 81, 1-23. https://doi.org/10.1016/j.ciies.2018.02.014

Sarr, B. (2015). Does indipendent regulation of utilities in developing countries improve efficiency?. The Electricity Journal, 28(6), 72-81. https://doi.org/10.1016/j.tej.2015.06.004

Schanes, K., Dobernig, K., \& Burcu, G. (2018). Food waste matters - A systematic review of household food waste practices and their policy implications. Journal of Cleaner Production, 182, 978-991. https://doi.org/10.1016/j.jclepro.2018.02.030

Schultze, W., \& Trommer, R. (2012). The concept of environmental performance and its measurement in empirical studies. Journal of Management Control, 22(4), 375-412. https://doi.org/10.1007/s00187-011-0146-3

Silva-Gao L. (2012). The Disclosure of Environmental Capital Expenditures: Evidence form the Electric Utility Sector in the USA. Corporate Social Responsibility and Environmental Management, 19, 240-252. https://doi.org/10.1002/csr.277

Simões, P., \& Marques, R. C. (2011). How does the operational environmental affect utility performance? A parametric study on the waste sector. Resources, Conservation and Recycling, 55, 695-702. https://doi.org/10.1016/j.resconrec.2011.02.001

Simões, P., \& Marques, R. C. (2012). On the economic performance of the waste sector. A literature review. Journal of Environmental Management, 106, 40-47. https://doi.org/10.1016/j.jenvman.2012.04.005

Simões, P., Cruz, N. F., \& Marques, R. C. (2012). The performance of private partners in the waste sector. Journal of Cleaner Production, 29(30), 214-221. https://doi.org/10.1016/j.jclepro.2012.01.027

Simões, P., De Witte, K., \& Marques, R. C. (2010). Regulatory structures and operational environment in the Portuguese waste sector. Wast Management, 30, 1130-1137. https://doi.org/10.1016/j.wasman.2009.12.015

Sueyoshi, T., \& Goto, M. (2009). Can environmental investment and expenditure enhance financial performance of US electric utility firms under the clean air act amendement of 1990?. Energy Policy, 37, 4819-4826. https://doi.org/10.1016/j.enpol.2009.06.038

Thanassoulis, E. (2002). Comparative performance measurement in regulation: the case of English and Welsh sewarage services. Journal of the Operational Research Society, 53(3), 292-302. https://doi.org/10.1057/palgrave.jors.2601160

Vigoda, E. (2002). From Responsiveness to collaboration: Governance, citizens, and the next generation of public administration. Public Administration Review, 62(5), 527-540. https://doi.org/10.1111/1540-6210.00235

Webster, J., \& Watson R. T. (2002). Analyzing the Past to Prepare for the Future: Writing a Literature Review. MIS Quarterly, 26(2), xiii-xxiii. Retrieved from http://www.jstor.org/stable/4132319

Wilhelm, R., \& Ruhlandt, S. (2018). The governance of smart cities: A systematic literature review, Cities, 81, 1-23. https://doi.org/10.1016/j.cities.2018.02.014

Williams, J. H., \& Kahrl, F. (2008). Electricity Reform and sustainable development in China. Environmental Research Letter, 3, 1-14. https://doi.org/10.1088/1748-9326/3/4/044009

Wolfswinkel, J. F., Furtmueller, E., \& Wilderom, C. P. M. (2013). Using grounded theory as a method for rigorously reviewing literature. European Journal of Information Systems, 22(1), 45-55. https://doi.org/10.1057/ejis.2011.51

Yarrow, G. (1986). Privatization in theory and practice. Economic Policy, 1(2), 324-377. https://doi.org/10.2307/1344560

Yusuf, Y. Y., Gunasekaran, A., Musa, A., El-Berishy, N. M., Abubakar, T., \& Ambursa, H. M. (2013). The UK oil and gas supply chains: An empirical analysis of adoption of sustainable measures and performance outcomes. International Journal of Production Economics, 146(2), 501-51. https://doi.org/10.1016/j.ijpe.2012.09.021

\section{Copyrights}

Copyright for this article is retained by the author(s), with first publication rights granted to the journal.

This is an open-access article distributed under the terms and conditions of the Creative Commons Attribution license (http://creativecommons.org/licenses/by/4.0/). 